\title{
The Silent 'Cosmopolitics' of Artefacts: Spectral Extractivism, Ownership and 'Obedient' Things in Cañaris (Peru)
}

\author{
Juan Javier Rivera Andia
}

This chapter explores the terms by which an Amerindian group establishes its relationship with the land in a local context marked by extractivism and the forms in which this relationship emerges in the Peruvian Andes today. ${ }^{1}$

The practices of exacerbated extractivism-as they are currently lived and suffered in this part of the world (Bury 2005; De Echave 2011; Sotelo and Francke 2011) -rest on the presumption, both implicit and explicit, of a situation in which a 'natural' land-object lies inert and is, above all, susceptible to being used and appropriated according to human needs and aptitudes (or at least those of people whose resources and means grant them 'priority' over others). What happens, however, if the Amerindian forms, as often described by Andean ethnography, by which 'nature' is experienced and understood stops being interpreted as mere belief or superstition? What do the practices of extractivism in the Andes become if we take seriously the idea that the environment is 'living' to the point that it constitutes a subjectivity (or maybe even a person) with its own will and

J. J. Rivera Andía $(\bowtie)$

Universitat Autònoma de Barcelona, Barcelona, Spain

(C) The Author(s) 2019

165

C. Vindal Ødegaard, J. J. Rivera Andía (eds.), Indigenous Life

Projects and Extractivism, Approaches to Social Inequality and

Difference, https://doi.org/10.1007/978-3-319-93435-8_7 
with whom a relationship in 'social' terms is unavoidable? What happens if we distance ourselves from the narrative of Peruvian presidents who speak of the 'absurd, pantheistic ideologies' of the indigenas - those who usually emerge as part of the 'social' or 'socio-environmental conflicts' (Howe 2015; Handelsman 2002; Merino 2015; Ombudsman's Office 2014; Huamaní and Macassi 2011; Huamaní et al. 2012) that seem to be an ever-growing consequence of extractivism - and leave open the possibility, in the Andes, of what Cesarino calls 'an ontology of multiplicity that is radically distinct from western conceptions of private property and metaphysical monisms' (2016: 192)?

These are just some of the questions that have been addressed by anthropology in the most recent debates concerning extractivism and the Amerindian peoples of South America. What interests me here is the exploration of a possible hypothesis relating to one particular part of the problem: the indigenous regimes of land ownership in contemporary rural Andes. With that aim, I examine a specific ethnographic case based on my own fieldwork: the practices and conceptions relating to the access and control of the land in the area of Cañaris, a Quechua-speaking region in the Peruvian Northern Sierra (approximately at the intersection of the departments of Lambeyeque, Cajamarca and Piura) which is currently influenced by a huge open-pit mining project. From this study, a nonhuman entity emerges that is much less 'natural' and 'indigenous' than those usually proffered by anthropological studies dedicated to 'Cosmopolitics' (Stengers 1996); this entity could be called a 'Catholic temple'.

Finally, my questions throughout this chapter concerning the land reveal the need to initiate an ethnographic reflection on the relevance or usefulness of some key concepts in Andean anthropology (such as comunidad campesina or 'communal lands'), and the ways in which they have conventionally been understood.

\section{On the Treatment of Land Ownership and Certain Nonhuman Entities in Contemporary Andean Studies}

As space constraints do not permit a comprehensive survey of Andean studies related to land, mining, and comunidades campesinas (nor do I consider myself equipped to do so), I limit myself to making some brief references to one particular aspect of these studies: their more or less tacit 
agreement as to what constitutes the land in the indigenous Andes. That is, to use a term that is somewhat in vogue, to its 'ontology'.

The literature on the use of land in one of the main Andean indigenous organisations recognised by the Peruvian state, called comunidades campesinas (Diez 2012), is without a doubt plentiful (Urrutia 1992). Studies into the struggles over access to the land involving indigenous peoples are also copious, as much in the case of historical battles against estates and big landowners (Blanco 1972; Malpica 1984), as in the more recent confrontations with large multinational corporations (Salas Carreño 2008; Lanegra 2008; De Echave et al. 2009; Bebbington and Bebbington 2012; Bebbington and Bury 2014).

Among the different problems explored by both groups of studies (those dedicated to the daily or structural use of the land and those concerning the conflicts over access to or ownership of the land), one can usually find references to: negotiations over access to the land, the administration of its use (e.g., whether for livestock or for agriculture); accompanying ideological or ritual support structures (boundary demarcation rites, for instance, or issues concerning the distribution of water for irrigation purposes or pasture for grazing cattle); the legal status of the rights of indigenous peoples; the dynamics of indigenous social protest movements (or the ones in which indigenous people participate); and the speeches and 'performances' of activists, leaders or intellectuals involved in national politics or the public sphere.

Despite considerable differences between the above-mentioned studies, one can find common ground in both viewpoints concerning land in the Andes. This common ground can be found even in those approaches, which make significant attempts to get closer to indigenous perspectives. It is present even as concerns the understanding of an Andean 'logic' or 'rationality' (cf. Golte 1987 [1980]), whether in analyses of the 'kingdoms' or pre-Columbian political entities (Murra 2002) or in studies of comunidades campesinas (Fonseca Martel and Mayer 1988; Golte 1987 [1980]; Urrutia 1992). It goes without saying that those studies dealing with agrarian reforms or mining disputes in the Andes usually leave unproblematised a certain understanding of what constitutes the land. In fact, few of the studies mentioned above question the appositeness of the elemental terminology of their basic conceptual tools- that is, a specific relation between a subject (whether a human person or a mixed collective such as the 'ayllu' or the 'community') and an object (whether that be as a continuous extension of land or as a discontinuous whole divided into 
'ecologic floors'). Indeed, even in the intelligent proposal of Murra's 'vertical archipelago', there is not much hint of a debate on anything that might be considered more fundamental than an ideal of complementarity' enabling the control of a maximum number of ecologic 'floors'. This fundamental level that I refer to, in the case of the Amerindian Andes, is the existence (or not) of a relationship that can be considered similar or translatable to the 'ownership' of the land.

Recently, Salas Carreño proposed that 'humans must be understood as products of sustained relationships with places. Humans emerge as persons - in a material, as well as moral, sense-through this web of social interactions with named places' (2016: 833); 'the relations among humans and the places where they live are built upon exactly the same notions through which [Quechua] human social relations are constructed' (2016: 815). Although Salas Carreño does not make explicit the issue of ownership nor if what he means by 'places' would include things such as buildings_-but see the quick mention of a 'house' (2016: 828)—he highlights an important feature of Andean socio-natural worlds: 'places themselves ... emerge as intentional agents' (2016: 821) which are members of collectives entangling humans and nonhumans. The code, one could say, used with these agents is food; in fact, as the vast ethnography about this topic shows, food production, circulation and destruction are constantly used not only as part of good will offerings but also of straightforward threats (Rivera Andía 2000). In this chapter, I will expand this suggestion into places that are constructed by humans, while I specify the mode of human social relationship that emerges in the case of the land in the Cañaris area. In this specific relationship, feeding intervenes but in a reversed direction, as proposed by Salas Carreño (2016: 825-827), from places to humans.

As mentioned above, the questions that this chapter raises around the 'ownership' of land in an extractivist context permit the visibility of a nonhuman entity that has a tenuous relationship with the subject at hand: a Catholic temple called Iglisya.

The Cañaris Catholic temple, whilst a nonhuman entity attributed with agency, may appear, at least, slightly 'peculiar' in the general context of the nonhuman entities described by studies of indigenous cosmologies of the Andes.

This invisibility in the Andean ethnography of buildings such as the Iglisya, which have been erected and used by indigenous peoples for centuries, seems to stem from being both Catholic and constructed. On the one hand, the Iglisya is something that is an emblematic part of 
the 'Christian' cult, in contrast to the nostalgic reconstructions proposed by those studies in search of 'Andean thinking' as something opposed to (or hidden beneath) something that is imagined to be completely 'western' or 'modern'. An ethnography of a Christian temple would allow us to question the subtle persistence (sometimes countered, other times avoided) of that image of the native or indigenous (inherited from the romantic Indigenism of the first half of the twentieth century), in the contemporary anthropology of the Andes.

On the other hand, the Iglisya constitutes an entity that is clearly 'artificial'. That is, it consists of something that is obviously man made, in contrast to the ideal of the 'untouched' which usually awakens notions of the 'natural'. The Iglisya then differs from other entities, which are usually (more) directly connected to the earth and are considered to be a constituent part of the environment (for a remarkable exception, see Tomasi 2015). Past and current ethnographies of the Andes usually speak of the mountains - under the name of apus, awkillos, or wamanis - of the lakescalled encantos (Larco 2008) - of the water itself (cf. Stensrud, this volume) or even directly of entities that seem to completely overlap with 'nature', such as the Pachamama or Pachatierra (Gow and Condori 1976). I have alluded elsewhere (Rivera Andía 2015b) to the anthropological perspectives of Tim Ingold on mounds and buildings. It suffices here, therefore, to recall the problems associated with the distinction between that which is made by human hands and that which has grown in the environment: 'Do we not rather have to conclude of things made or built, as much as of things grown, that they are originating all the time' (Ingold 2013: 81)? It would be rather more useful to analyse the reasons behind the frequency or persistence of 'natural' (or nonartificial) features in the nonhuman entities highlighted by the studies regarding the cosmologies of the Andes.

The Iglisya, however, quite apart from being Christian and artificial, has a third characteristic that accentuates its outlandishness or peculiarity. This building is also a political entity to the extent to which it constitutes an alternative to one of the key assertions of extractivism concerning the ontology of land and the relationships extractivism establishes with it. The relationship with the land as a natural object is, silently but constantly, provoked by the spectre of extractivism in Cañaris: it could be said that the mining project and its governmental allies need that type of land (i.e., as natural object) to exist heedless of how troublesome its emergence might be (Blaser and de la Cadena 2017: 186). It is indeed this situation that converts a temple into a device for political intervention. How does the 
temple interfere, interrupt, or disturb the extractivist relationship with the land-object? As I show, the temple not only allocates and controls access to the land (which I refer to below as its administrative quality) but also emphasises those qualities of the relationship with the land that I would describe as those that sustain 'the living' or what Gan et al. call 'livability' (2017: G9). The Iglisya does so from two sides: by its generative or lifegiving dimensions (which I call the condensing aspect of the temple) and by its quality as a living entity dependent on human care (which I designate as its obedient quality).

Nevertheless, although it is involved in the local political game, the temple of Incahuasi remains invisible (Rivera Andía 2013, 2015b) or 'non-existent' (Escobar 2016) not only in the relationship between Cañarenses and La Minera (The Mining, as it is called by the people of Cañaris) but also in the subtle ethnographic explorations that try to distort or broaden the elements usually allowed within their scope (de la Cadena 2014; Schavelzon 2016: 118-119). Some of the causes of the scant visibility or existence of nonhuman entities, such as the Iglisya, can probably be linked to what I have pointed out: the temple is obviously artificial and explicitly Christian.

The political role of the Iglisya, moreover, involves neither its direct and explicit intervention nor overt demands on the public platforms that promote negotiations to resolve 'social conflicts' between the indigenous authorities in Cañaris and La Minera (or the government agencies that back it). In spite of its political importance, the participation of the Iglisya in these negotiations is neither invoked by the indigenous inhabitants of Cañaris nor authorised by their non-indigenous counterparts. Accordingly, the Iglisya does not enter into the public arena as part of a political discourse related to the ethical substance of indigeneity (as in the case described by Fabricant and Postero, this volume); nor is this building alluded to by political activists linked to international environmental networks (as is analysed by Li and Peñafiel, this volume). What remains of the political then in the emergence of this nonhuman entity?

In order to answer this question, the Iglisya requires us to make a rather serious conceptual revision of the terms in which one addresses these negotiations. Such is the intention of this chapter, which broaches an analysis of the Iglisya as a device for the ontological constitution of the land (one of the key elements of the social conflicts associated with mining in the Andes). Further definition may still be necessary. 
The force that drives this chapter is not entirely similar to the one behind those studies dedicated to indigenous conceptions of 'landscape', 'space', or 'places' (Pérez Galán 2004; Salvia 2014; Robin 2010; Rivera Andía 2005), where it is more or less accepted that an indigenous society is representing (and living in or with) the same ('natural') spaces differently. That is to say, this chapter does not require us to affirm or deny the existence of a world 'out there' that humans interpret or know in varying ways (according to their 'cultures', 'epistemologies', or 'intellectual frameworks'). It is enough to consider the Iglisya as 'a set of embodied skills and subjectivities ... a set of practices that array-and enact-a particular kind of person' (Law and Lien 2012: 4; see also Latour 2014a) and a particular kind of land. Without 'grounding the possibility of political difference in a prior story of how the world(s) must work' (Holbraad and Pedersen 2017: 54), the Iglisya as a child constitutes a type of land that is not fully encompassed, either by the mining operations' land or by the conservationists' land.

What I work to comprehend, instead, is a type of relationship with the land that implies a mutual constitution between it, humans (gathered together in this case in the comunidad campesina), and other nonhuman entities that, like the Iglisya, may or may not be part of the publicised negotiations around 'social conflicts' (Arellano-Yanguas 2011; Panfichi 2011; Tanaka 2012; Meléndez 2004). This emphasis on alternative ontologies of the human-land relationship (whether revealed in the public arena of social conflicts or not) is inspired by the contemporary debates around the 'systems of ownership' in the South American lowlands (Di Giminiani 2015; Brightman et al. 2016), some of which are, in turn, part of wider discussions around the dynamics of 'familiarisation' (Fausto 2012 [2001]), the composition of worlds (Descola 2014a), and the 'ontogenic' processes (Ingold in Descola and Ingold 2014) among indigenous groups.

\section{Extractivist Contingencies: A Spectre Haunts CaÑaris}

I have described in previous studies some of the distinctive characteristics of the indigenous group that inhabits the Cañaris area (Rivera Andía 2013, 2014a, 2015b; Rivera Andía et al. 2017) and the vicissitudes of the 'spectre of mining' in the mountains of the province of Ferreñafe (in the Peruvian department of Lambayeque) (Rivera Andía and Snowdon 2013). 
It is enough here to recall some aspects linked to the 'spectral' nature of the mining industry and the 'invisible' nature of the inhabitants of the Cañaris area. I start with this latter point. On the one hand, it could be said that the people of Cañaris have remained invisible, not only because of the usual subordination of modern-day indigenous constituent groups in the Peruvian public sphere but also because of the monopoly on 'indigeneity' that their southern counterparts (centred around an image of an 'imperial Cuzco') hold in the country's popular imagination. However, this 'invisibilisation' or 'actively produced non-existence' (Escobar 2016) has another aspect which, rather than being about pure negation, is more about disguise. In the same way that they are negated, the people of Cañaris are also affirmed. In serious circumstances, such as the brutal repression suffered during protests in 2013, they are treated as 'terrorists', a frequently used term in Peru's recent history (cf. González 2012). In situations of 'slow violence' (Nixon 2013), which is less dramatic but more persistent, the catch-all term used to label the existence of the people of Cañaris is 'poverty' (Eversole et al. 2005). In fact, one of the most frequent narratives recurring in the extractivist context in Cañaris is the description of the people of Cañaris as 'poor' (Rivera Andía 2014a). The label 'poverty' in the current national official discourse is used to describe living conditions characteristic of the predominant way of life in the Cañaris region and other parts of the Peruvian highlands, conditions which are usually considered indicative of need. In the context of the national and academic 'invisibility' that affects Cañaris, one of the ways in which its inhabitants have occasionally become more visible has been precisely through the label of poverty. Used as a form of stigma, this label is, above all, yet another way of continuing to ignore the rights of the Cañaris people as an indigenous group (De Echave et al. 2009; Merino 2012; Hallazi Méndez 2013; High 2015: 115, 179). The strategies by which the people of Cañaris criticise the external imposition of the label of poverty are dynamic and constantly changing. Nevertheless, these strategies are usually linked to some extent to religious practices, which have churches such as the Iglisya as their centre. In these cases, the ownership of land and agricultural work are reasserted as sources of wealth through renowned religious rituals in which only landowners may participate and where multiple expressions of life- and wealth-generative capacities of land unfold. In previous work, I have considered these as a collective, critical, and nonverbal reflection (Geertz 1973) of external attempts at stigmatisation (Rivera Andía 2014a). 
The 'ghostly extractivism' to which I refer relates to an open-pit mining project generically known as 'Cañariaco' that has been owned by the Canadian mining company Candente Copper since at least the first decade of this century (Candente Copper Corp 2011). Through my use of the term 'spectral extractivism', I hope to highlight the situation in which 'disaster would seem to start with the hopes and expectations that people entertain some time before, or independently of, the start of commercial oil extraction' (Weszkalnys 2016: 230). Nevertheless, ghostly extractivism differs from what other scholars have called 'the temporal politics of a disaster yet to come' in one key respect: The Cañaris area anticipation is much more tainted by anxiety and much less supplied with large-scale prevention devices than other cases shadowed by the 'resource curse' (Weszkalnys 2016: 228). The lack of anticipation is unfortunately also a function of the lack of information about mining operations that affects the Cañarenses.

In 2013, the first protest by the inhabitants of this region was brutally suppressed (La República 2013) when community members tried to block the access road to the mining camp (both of which are located on their lands) from which the explorations and measurements of the extractable minerals are carried out. To a certain extent, this was a protest against a spectre, against an entity of rather huge proportions, ambiguous, and tentacular, whose various components had for some time incessantly and drastically interfered in local politics, the economy, and landscape. This phantom-called, as mentioned above, La Minera-emerges fundamentally from the intersection of three factors: the international price of certain metals (in particular: gold, silver, and copper), the legal and illegal subterfuges of the organisations that benefit from the mineral extraction (Gudynas 2011, 2018), and, finally, the invisibility to which the greater part of the indigenous world of Cañaris is subjected.

Like all spectres, the presence of La Minera generates a considerable amount of 'anxiety' (Bessire 2014), likely due in part to La Minera's pursuit of the measureable, be it in the richness of the deposits or in the demarcation of the lands in which the mine will operate (just as Marc Brightman, this volume, points out in the Surinamese case). However, this anxiety is related likewise to the magnitude of the mining concessions made by the Peruvian government to La Minera, concessions that imply loss of land and contamination and scarcity of irrigation water (as Astrid Stensrud, this volume, describes regarding another Peruvian case), and 
have led to the physical destruction of the town, including the main square and the church (Silva Santisteban 2013). Indeed, the scope of the planned open-pit mine, processing plant, and deposits of tailings and waste rock leave little room for doubt about the radical changes to the environment and, consequently, the way of life for the people of Cañaris (as is the case in other parts of the world where sustainability is reduced to an oxymoron and development programme agents are transformed into collaborators; see Rajak 2011; Rajak and Gilberthorpe 2016; Connell and Howitt 1991).

Whatever their reaction to the spectre of La Minera, for the people of Cañaris, it brings the inevitability of transformation, drastic or gentle, of the land and rural life in the Cañaris area.

In addition to contrasting attitudes to the mining project among and within the comunidades campesinas of the Cañaris area, there are different degrees of unease according to how drastic the transformations are expected to be. I give three examples of adjoining comunidades campesinas in the area. At one extreme is the comunidad campesina of Cañaris, which has the camp for the mining project inside its communal lands: the tension here is at its highest. At the other extreme stands the comunidad campesina of Penachí, whose lands are not affected, so far, by the project: attitudes here border on indifference. The intermediate case can be illustrated by the comunidad campesina of Incahuasi: the road that has been built to access the mining camp passes very close by the principal town but is not within their boundaries. In short, the inhabitants of Incahuasi show both enthusiasm and fear but in a way that is neither as moderate as it is among the people of Penachí nor as pronounced as among the inhabitants of Cañaris.

To describe the established relationships with the land in the Cañaris area, I look to the case of Incahuasi, which is relatively nearby those who would be directly affected by La Minera: the members of the comunidad campesina of Cañaris. The reason for choosing Incahuasi is not only because it has most of the distinguishing characteristics of the Cañaris area nor that some of its organisations support the claims and protests against La Minera but is based on something more historically profound: Incahuasi is a direct product of the indigenous battle waged by those who are now its neighbours. The town was founded in 1747 by the 'Indians' of Penachí and Cañaris who built the Iglisya as an open act of defiance against the large-scale landowners who then controlled those lands. Its establishment was part of a series of actions carried out by the 'Indians' of 
Cañaris and Penachí to take over the land using all the legal methods at their disposal as well as some practices that were distinctly outside the law. Almost 300 years after its construction, their temple, the Iglisya, has finally become the principal nucleus of a political unit whose small towns and villages are today precisely those locations from which powerful others tried to gain control of the people of Cañaris.

There is, however, another even more crucial reason for us to centre our gaze on Incahuasi: the presence of a device constructed explicitly for such a struggle for the land. I am referring to an entity that is still somehow unusual in the context of Amerindian studies: a Catholic temple. Indeed, all the ethnographic and historical investigations (my own fieldwork included) into the control of land in the Cañaris area has led to this architectural complex. Its synchronic and diachronic analysis will help us understand not only the development but also the actual configuration of the relationships that humans establish with their lands in this region of the Andes.

\section{A Multiple Artefact: The Iglisra}

The few studies into religious buildings in Northern Peru have benefitted from various recent publications. ${ }^{2}$ Absent from these valuable contributions, however, is the place of a Catholic temple like the Iglisya in an environment where personhood reaches far beyond the world of the human (Rivera Andía 2008). Indeed, if in numerous Amerindian cases 'an object is nothing more than a subject that is incompletely understood' (Coelho de Souza 2016: 183), there arises the problem of how to understand objects which, like the adobe temple, have not only personhood but life.

The main issue at stake was the conceptualization of artefacts in a world in which the subject-object distinction is by definition fuzzy (and even inapplicable). What is the place of artefacts in a universe where personhood extends far beyond the human? (Brightman et al. 2016: 11)

I address this question in the following three discussions on the multiplicity of the church.

This extraordinary piece of architecture in the Cañaris area, the Iglisya, is an historical product of the indigenous struggle for the land throughout this entire region (Rivera Andía et al. 2017; Rivera Andía 2015a). Indeed, 
the building emerged out of the strategies of the indigenous people for the control and defence of their lands, constructed clandestinely in the middle of the eighteenth century during the final years of the viceroyalty of Peru (Huertas 1996). As such, the Iglisya is an historic milestone that crystallises indigenous control (to the detriment of the large-scale local landowners) of a set of lands that form the basis of what today is the comunidad campesina.

During my fieldwork (carried out between 2009 and 2013), at least three fundamental aspects of this building, the Iglisya, stood out: the administrative - expressed in its prerogatives over the distribution and control of land (Rivera Andía 2015b); the condensing-related to those aspects of it that are life-generating; and the obedient-related to the Amerindian perception of things as dependent or 'fully subjected' (Brightman et al. 2016: 12) (Fig. 7.1).

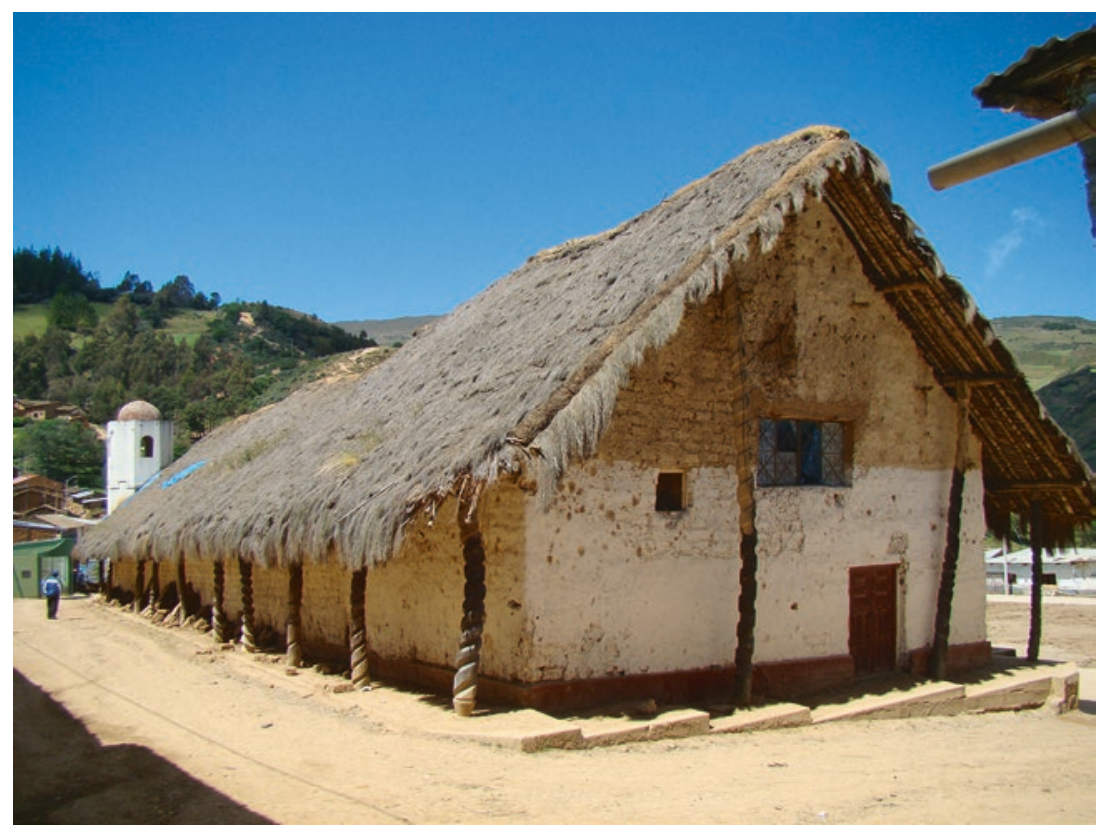

Fig. 7.1 The Iglisya of Incahuasi 


\section{An Iglisya-Land: Emergence and Functions of a Material Device}

The Iglisya functions as an administrative device in two respects. The first involves distribution. The thatched roof (made of jarava ichu) is divided into sections where ritual maintenance (carried out every five to ten years) is overseen by kinship groups (ayllus) or small villages that comprise the owners of the lands of Incahuasi. The distribution of the roof surface between these kinship groups is explicitly analogous to the distribution of the lands of Incahuasi between the same groups-and the division into two groups established by the ridge of the roof is analogous to the division established by the river that crosses the valley (Carrasco 2018).

The second aspect of this administration is expressed in the control of the access to land through the heads of kinship groups (cabezarios). ${ }^{3}$ The management of the Iglisya's main contents (namely, the Catholic statues) corresponds directly to the appropriation of the benefits derived from working the parcels of land corresponding to those statues. For example, only the kinship group of the cabezario charged with observing the ritual honours of Santa Rosa de Lima have access to the lands belonging to her and the products of those lands. Carrasco's (2014: 27-30) study of the Incahuasi contemporary archives confirms how the annual celebrations by the brotherhoods around the temple statues function as a legitimisation ritual (Rappaport 1999) of the ownership of the land. Today, more than half a century after the formal recognition of the indigenous community of Incahuasi by the Republic of Peru in 1963 - and, thereby, of their collective lands - community members continue to affirm that their lands 'belong' to the statues that live in the Iglisya (Vreeland 1993; Shaver 1992: 236).

Even if I were to end our considerations of the relationship between the temple and the land at this point, I could, perhaps, still affirm that this architectural object is actually a church land in the sense that it not only 'represents' the relationship that the inhabitants of the Cañaris area have with the land but embodies and constitutes that relationship (see Bloch 1998). On the one hand, the two sets of rituals performed in the Cañaris area (the fiestas patronales financed by the cabezarios and the collective renovation of the roof of the Iglisya) celebrate, legitimate, and constitute control over the land. On the other hand, the Iglisya, which serves as both the focal point and the refuge for the rituals, is the historical result of the struggle for that control over the land. Both types of exploration, the 
ethnographic and the historical, are strengthened by a common assertion over the mutual constitution (or ontological composition) of people and lands in the Cañaris area (Rivera Andía 2015b). The land as constituted by the Iglisya is not merely an historically disputed object (previously, between 'Indians' and landowners, nowadays, between farmers and mining companies). The land here is also part of a collective where it co-emerges (de la Cadena 2015: 102, 143; see also Canessa 2017: 549-550) with the people of Cañaris. In this way, the division of the lands and the kinship groups that tend them are mutually constituted through the rituals sheltered by the Iglisya and the material being of its own architecture. This mutual constitution can be thought of as a type of cartography in the sense that the church land not only represents but incessantly produces its surroundings in such a way that the boundaries between the different ontologies or resulting worlds are constantly realigning themselves (Blaser 2009: 16). In short, although I do not linger on this variant of 'ontological anthropology'-which tries to state something about what there actually is in the world (Holbraad and Pedersen 2017: 46-54) — it may be correct to assert that the temple is the relationship between humans and the land (Mol 1999; Blaser 2009; de la Cadena 2014). We could go so far as to say that the Iglisya (as an indigenous tool for the access to land ownership) could have a greater significance than the land itself: 'the weight appears to lie less in things ... and more on the conditions of the relationships by which knowledge becomes possible-less, therefore, on property, but more on the technologies or modes of transformation that allow access to the field of relationships' (Cesarino 2016: 202).

\section{An Alive and Generating-Life Iglisya}

In the second fundamental aspect of the temple, condensing, the Iglisya participates in the ritual and cosmological dynamic in Incahuasi, like an assemblage of the livability or life-giving properties attributed to the land—or, as Salas Carreño puts it, 'named places' (2016: 833). Through the statues that it houses and the altars that line its walls, the people of Incahuasi foster the fertility of their lands and the reproduction of the cattle that graze on those lands. The Iglisya condenses, in this way, the vitality of the land. Herein lies its living aspect: fertiliser or producer of life, the aspect that matters most in farming communities.

I am not going to linger here on the familiar topics of contemporary Andean indigenous ethnography—as, for instance, cattle branding rites 
(Rivera Andía 2003)—nor on the more recent perspectives on the components of living usually labelled 'anthropology of life' (Arnold 2017). However, I would like to highlight two tendencies: on the one hand, a definition of 'ontology' alludes to how a particular world is composedwhat its different components are-in accordance with the general disposition specified for each form of identification, as, for example, proposed by Philippe Descola (2014b: 437). An ontology, here, is based on something 'more elemental' (Descola 2014a: 239) than a cosmology. Rather, it is founded on 'systems of properties that humans ascribe to beings' (Descola 2006: 139), on 'generative patterns of inferences and actions, ways of composing the world and uses that follow analogous principles and that, for that reason, can be propagated in very similar forms and in very diverse historical contexts' (Descola 2014a: 112 and 236-237). In short, although Descola is conscious of the role played by 'historical contexts', the composition of a world is for him, above all, a matter of perception, of actualisation and of detection (or of omission) of the qualities of our environment and the relationships that are established in it (Descola in Descola and Ingold 2014: 30). On the other hand, some authors, such as Tim Ingold, have emphasised the procedural aspect of this notion of a world's composition, conceiving of it as 'a continuous process ... [a] perpetual development.... To compose a world is not to represent life as though it existed beforehand, but to make life emerge as it grows' (Ingold in Descola and Ingold 2014: 37-38, author's translation). My intention here is not to discuss the differences between two authors who are so complex and prolific. I content myself with highlighting two possible emphases of the so-called composition of the worlds: one which is considered a form of perception, actualisation, and detection of certain qualities and the other which is thought of more as a construction, a development, or a type of instigation for life to grow (Hallam and Ingold 2014). This contrast highlights a relationship between the emphasis on the development of those elements that compose a world and the emphasis on the 'living' aspects that they have. Both facets seem to be underlined by the relationship between the people and the land in the Cañaris area: the Iglisya is not just an historically constituted device but also a 'living' component of the world. This process of mutual constitution recalls what Ingold has called-in his critique of the concept of ontology-an 'ontogeny' (ontogénie) in his emphasis on the inevitable temporality of continuous human evolution (Ingold in Descola and Ingold 2014: 37). The relevance of the study of 'temporalities' in the study of the systems of land 
ownership in South America has been highlighted by Viegas (2016: 252): ' $[\mathrm{T}]$ emporalities should be considered a key perspective in the understanding of the lived experience of possession, namely in the history of entanglements in the possession of land.' I now move on to discuss the third fundamental aspect of the Iglisya, the obedient. To my knowledge, this aspect has not been addressed previously in Andean ethnographies of indigenous buildings or artefacts.

\section{A Church-Child: On Obedient Entities in the Andes}

This third fundamental aspect of the Iglisya becomes evident when the building is, symbolically and tacitly as well as concretely and explicitly, conceived of and treated as an obedient entity. During the periodic renovation of its roof-through a ritual called Iglisya qatay, which has been far less documented by ethnography than, for example, the roofing rituals of newly built family houses (Gose 1991) - the temple is treated like a child and is given a ritual haircutting ( rutu chikuy, or as it is called locally, landa) (Rivera Andía 2015b). Indeed, the Iglisya qatay follows the same sequence as the well-known pre-Columbian ritual still found throughout the Andes during which a child has its first haircut in exchange for ribbon tassels and donations, progressively integrating the infant into the human world. During the Iglisya qatay, the roof of the church is treated in the same way as a child's hair during the landa ceremony; both rituals have the same protagonists, songs, elements, and sequences (Rivera Andía 2015b). The building appears, then, not just as a living being but more specifically as a human child. More precisely still, it is treated as a certain kind of child: one that is being put through the first phases of its gradual incorporation into the society of upright and honest humans (runa), in the way that this is understood in the Andes (Ortiz Rescaniere 1999).

Let's return to the above-mentioned feeding relationship between (Quechua) humans and places in the Peruvian Southern Andes. As we have seen, among the Cañarenses or Quechua of Cañaris, humans treat their lands as do their children. If this is a correct interpretation, then the anomaly that Salas Carreño could not help but detect in Cuzco would be resolved. He observes that ' $[\mathrm{t}]$ he relations between human parents and their children are slightly different from those between places and humans. While children do not feed their human parents, humans must continually feed places' (Salas Carreño 2016: 828). What happens then when humans leave the role of the child who is nurtured by the land and take instead the 
role of those who nurture the land as one would a child? I suggest that this view allows us to explain the apparent incongruity of the statement above: the land is fed by humans because they are meant to do so, as they do with their children. This is, of course, a case in which humans are not permanently obliged to respect or fear powerful nonhumans. In this regard, the Cañaris ethnography and other examples (Rivera Andía 2000) recant the 'strong hierarchical relationship, with humans dependent on the places' goodwill' depicted in Cuzco (Salas Carreño 2016: 829). The Iglisya shows that a place (if not the land as well) can certainly be dependent on human goodwill. Therefore, rather than a 'strong asymmetry of power', in the case of land ownership in Cañaris, I see a symmetric confrontation or fight between humans and nonhumans. ${ }^{4}$

This ritual treatment of the Iglisya as a child establishes a close relationship between the control of the land and the 'nurturing' values and practices of the people of Cañaris. In this way, it personifies an indigenous form of conceiving of and putting into practice the ownership, not just of buildings but, above all, of the land. This analogy between childhood and the device for control of the land that is the Iglisya suggests a central role in the exercising of ownership and of care and nurture, whether it be of nonhuman entities or of human beings as children: 'care and nurture play a central role in the ownership of places' (Brightman et al. 2016: 24). The relevance for this Andean case, as well as of the perspectives of the authors gathered in this collection dedicated to 'ownership' and 'nurture' in the Amazon, will become ever more evident from this point on.

What I wish to highlight in this chapter are the logical consequences of this analogy between the Iglisya-land and human childhood: both are treated and understood as being under the care of human kinship groups that comprise the comunidad campesina:

\begin{abstract}
[A]ppropriating and nurturing acts of "domestication" are often necessary to maintain their [the object's] status... As Erikson (2009: 188) suggests, in Amazonia "things", rather than being conceived as independent subjects, seem to be considered as semi-autonomous subordinates. In other words, "things" seem to be less perceived as full subjects than as fully subjected ... submitted to an "overt life" of dependency as "obedient things" in much the same way as children, captives, clients and pets are. (Brightman et al. 2016: 12)
\end{abstract}

The ritual treatment of the Iglisya as a child implies that it is not a complete subject as such but rather a subordinate or dependent entity. Therefore, there is more than a building (made for and by the 'Indians') as 
a milestone in the historical process of the constitution of their actual communal lands. Additionally, the 'creativity' exalted in its clandestine foundation and unusual architecture seems to be closely connected to a process of care or 'familiarisation' of these lands:

The ownership of nonbuman persons is part of the process of place-making. Creativity begets ownership, and the making of artefacts may create new persons ... who may be in turn become owners themselves. Such processes of creative appropriation are ... very close to the familiarizing processes of nurture. (Brightman et al. 2016: 11)

The comparative possibilities between 'Andean' and 'Amazonian' cases are obviously outside the remit of this chapter. Leaving such a theme for future studies, I return here to our ethnographic case from the Peruvian Sierra in order to concentrate on its own specific characteristics. In sum, two findings (one hierarchical association and another symmetrical one) allow us to develop a hypothesis concerning the type of relationship that humans establish with the land in the Cañaris area. A hierarchical relationship, as noted above, is established between humans and the Iglisya, which places it in the category of obedient entities identified in the ethnography of the South American lowlands with children, captives, clients, or pets. What appears to emerge here, then, is the configuration of an Iglisya-child.

There is a symmetrical relationship, as established above, between the Iglisya and the land. Whether the Iglisya is an historical product of the land or an ethnographic artefact for the distribution and control of it, this relationship calls attention to the emergence of an Iglisya-land. It is worth remembering, in passing, that the building in question is literally constructed of two things extracted from the land: earth (the principal material of the sun-dried adobe bricks that form its walls) and the plants that grow on the thatched roof (Carrasco et al. 2016).

The hypothesis then, is as follows: if the relationship that humans have with the land materialises in the Iglisya (or is represented by it, or simply is it), and if the Iglisya is treated as and conceived of as an obedient entity, is the relationship between these people and this land then analogous to the one that they have with children? Is the land here included among the still not completely human entities, which need to be fed and cared for? Is the relationship that the people have with the land understood and staged in the terms used to care for an obedient subject that is in the process (always incomplete) of becoming human? 


\section{Final Considerations}

This chapter offers an ethnography that seeks to overcome the invisibility and asymmetry to which indigenous groups such as the Cañarenses have historically been subjected and to provide an empirical basis for an argument about mining's role in the reproduction of social and environmental inequality in the Andes. This is particularly the case nowadays as increasing numbers of mining corporations' projects threaten ways of life-while state agencies simultaneously commoditise an essentialised culture of the area (as is currently being done [cf. Martínez 2017]). The simultaneity of these processes should not be surprising if we remember that both ' $[S]$ tate agencies and mining corporations are usually much better positioned to commission and direct ethnographic research or to exploit ethnographic knowledge' (Ballard and Banks 2003: 306).

In the Cañaris area, collectives are extended to include not only runas and santospatrones and places like the mountains and the lakes (as described by Andean ethnography and by both Ødegaard and Stensrud, this volume; see also Salas Carreño 2016) but also other nonhuman entities that have been historically constituted by humans, like the Iglisya. Its relevance emerges from what Latour considers 'the crucial political task': 'to distribute agency as far and in as differentiated a way as possible' (Latour 2014a: 15). Although rather different from a 'sacred' entity that must be 'respected' (Cepek 2016) and is part of or identifies itself with 'nature', the significance of this indigenous artefact for the Cañarenses largely exceeds the categories of 'religion', 'culture', or 'patrimony'. Far from presupposing any kind of 'non-modern ontological bases' (Schavelzon 2016: 132), the Iglisya's existence stands only on 'relational contrasts produced in acts of comparing one set of purported commonalities with another' (Salmond in Boellstorff 2016: 402). But even if considered as nothing more than a mining-activated provisional 'quasi-object' (Cepek 2016), the politics of the Iglisya (and of the relationships it embodies) is as crucial as that which involves the historic struggle for control of the land. At the same time, the Iglisya is an entity under human care, as is the land itself. Both are interwoven in many ways: the land provides the raw materials used to build the Iglisya; the Iglisya, in turn, distributes, organises, and periodically produces the land. Both Iglisya and land constitute the de facto Cañaris collective. How do we make 'operational' or recognisable, de jure, the 'Cosmopolitic' (Stengers 1996; see also Blaser and de la Cadena 2017:186; Schavelzon 2016: 123) of this collective in the face of 
the real-existing post-neoliberal regime that imbues the Cañaris area (Arsel et al. 2016; Bury 2005)? Is it appropriate to revisit the omnipresent denomination comunidad campesina when it comes to recognising the politically and economically relevant groups in this region of the world, which has been profoundly saturated with resource extraction? What then would constitute 'communal lands' in a situation where the land is part of a relationship such as that embodied by the Iglisya? How would our ethnographic understanding of the comunidad campesina be affected if ownership of the land were based on such radically different principles and if the exclusively human collectives were not those relevant in the political sphere? Is it possible, finally, to make the legal aspect of this relationship operational in the national sphere, above all in a situation such as the current one, marked by the struggles that have arisen as a result of the Latin American 'extractivist imperative' (Arsel et al. 2016)?

If the hypothesis that I am formulating holds, then yet another threat could be added to the already long list associated with spectral extractivism in the Cañaris area. I am referring to the suppression of a specific form of relationship that, until now, would have been crucial for the existence of the community of humans and nonhumans such as the one found in this part of the Andes. To threaten this relationship would be to eliminate a group, a world, and a way of life that specifically and probably precedes (Brightman et al. 2016: 3) those trying to replace it.

In the case that concerns us here, that of architecture and ownership of the land, La Minera also plays a role analogous to that of those external agents who are either trying to demolish the Iglisya in order to build a church of concrete (the mayors with their life-projects focused on the urban Spanish-speaking world on the north coast of Peru) or to neglect it until it falls into a ruin (the members of the religious groups created by the Summer Institute of Linguistics).

In a situation as persistently intimidating as this one, it seems difficult to envisage the relationships that are materialised in the Iglisya as a 'threat' to modernity - in the sense that Mario Blaser (2009) uses this term when describing the $Y r m o$ of the Yshiro in Paraguay-or as a predatory aspect of the alternative world the Iglisya constitutes (Brightman et al. 2016: 3). Indeed, the practices materialised by the Iglisya and the ones corresponding to spectral extractivism might be rather 'kept in a field of equivocations because they do not severely interrupt each other or irremediably disrupt the commoning work' (Blaser and de la Cadena 2017: 190). I would, therefore, be content to glimpse in the Iglisya a 
fighting implement (always available although not continuously used) in the 'war' of worlds that some authors have recently described (Latour 2009, 2014a: 5, b, 2015; Viveiros de Castro 1999, 2015a, b; Schavelzon 2016: 126). The relevance of the Iglisya as a device in the struggle for the land certainly relies does not rely on its visibility neither in the public sphere nor scholarly literature-where earth-beings are usually described in terms of respect or resistance (cf. Merino 2015: 86; Rénique 2009). It does not figure in public speeches nor is it invoked by activists involved in resistance against La Minera (which increasingly receives public attention in the forms described by $\mathrm{Li}$ and Paredes Peñafiel, this volume). Nor do we find southern earth-beings as apus-also described by Stensrud and Ødegaard, this volume-invoked explicitly in indigenous organised protests. It is possible, however, that the prevalence of the material, collective, and nonverbal aspects of the relationships woven into the Iglisya can be considered as part of 'a cosmopolitical economy of persons both human and nonhuman' (Brightman et al. 2016: 24) that might configure a 'Cosmopolitics' (Stengers 1996) if our current conceptualisations about "whom, precisely, is one "taking seriously"' and "how "other" the otherwise can be' (Candea 2014) are expanded.

Finally, we should perhaps remember the relevance of an 'ontography' (Holbraad 2009, 2014, 2017) compromised by the description of those worlds that interrupt 'the one-world story' (Escobar 2016: 22). If anything were to suggest itself as salvageable from the rivers of ink that have unleashed the current discussions about the 'ontological turn', perhaps it would be the obsessive methodological emphasis on the 'reflectivity' of our own concepts around ethnographic contingencies (Holbraad and Pedersen 2017). Through this chapter, I hope to contribute to the accompaniment of just such a conceptual reflectivity with its preoccupation for the frictions, inequalities, and hierarchies that make the world of Cañaris something 'actively produced as non-existent' (Escobar 2016: 15).

Acknowledgements The author would like to thank Margaux Majewska, Marieka Sax, Cecilie Vindal Ødegaard, Marc Brightman and Katharine Wheeler for their critical readings and constructive suggestions for revisions of the initial manuscript. I also wish to thank the Marie Curie Alumni Association (MCAA) for its support during the writing of this chapter. A good deal of the motivation to write this chapter comes from the huge and wide-ranging impacts mining has had in both my personal history and that of my family, natives of the Peruvian Central highlands and workers of some the many sections of Centromín Peru surrounding La Oroya refinery and Cerro de Pasco open pit mine. 


\section{Notes}

1. For a definition of extractivism, see the Introduction by Rivera Andía and $\varnothing$ degaard, this volume.

2. I have reviewed (Rivera Andía 2016) and listed (Rivera Andía 2014b) these publications previously.

3 . The relationship between land (claims), residence, and ties to locality and to kin have been studied in the Andes (Salas Carreño 2016) and elsewhere (Ballard 1997; Jorgensen 2010): 'land condenses a host of social relationships for which territory serves as a form of shorthand reference' (Ballard and Banks 2003: 300).

4. Although the case discussed here deals with the struggle for land ownership, I have previously described other situations in which ownership of other things (such as cattle) is disputed in indigenous terms (Rivera Andía 2003).

\section{REFERENCES}

Arellano-Yanguas, Javier. 2011. ¿Minería sin fronteras? Conflicto y desarrollo en regions mineras del Perú. Lima: IEP, PUCP.

Arnold, Denise. 2017. Hacia una antropología de la vida en los Andes. In El desarrollo y lo sagrado en los Andes. Resignificaciones, interpretaciones y propuestas en la cosmo-praxis, ed. Heydi Galarza. La Paz: ISEAT.

Arsel, Murat, Barbara Hogenboom, and Lorenzo Pellegrini. 2016. The Extractive Imperative in Latin America. The Extractive Industries and Society 3 (4): 880-887.

Ballard, Chris. 1997. It's the Land, Stupid! The Moral Economy of Resource Ownership in Papua New Guinea. In The Governance of Common Property in the Pacific Region, ed. Peter Larmour. Canberra: Australian National University.

Ballard, Chris, and Glenn Banks. 2003. Resource Wars: The Anthropology of Mining. Annual Review of Anthropology 32: 287-313.

Bebbington, Anthony, and Denise Bebbington. 2012. Post-What? Extractive Industries, Narratives of Development and Socio-Environmental Disputes Across the (Ostensibly Changing) Andean Region. In New Political Spaces in Latin American Natural Resource Governance, ed. H. Haarstad. London: Palgrave Macmillan.

Bebbington, Anthony, and Jeffrey Bury, eds. 2014. Subterranean Struggles. New Dynamics of Mining, Oil, and Gas in Latin America. Austin: University of Texas Press.

Bessire, Lucas. 2014. Behold the Black Caiman: A Chronicle of Ayoreo Life. Chicago: University of Chicago Press.

Blanco, Hugo. 1972. Tierra o muerte. Mexico City: Siglo XXI.

Blaser, Mario. 2009. The Threat of the Yrmo: The Political Ontology of a Sustainable Hunting Program. American Anthropologist 111 (1): 10-20. 
Blaser, Mario, and Marisol de la Cadena. 2017. The Uncommons: An Introduction. Anthropologica 59: 185-193.

Bloch, Maurice. 1998. The Resurrection of the House Amongst the Zafimaniry of Madagascar. In How We Think They Think, ed. Maurice Bloch. Boulder: Westview Press.

Boellstorff, Tom. 2016. For Whom the Ontology Turns. Theorizing the Digital Real. Current Anthropology 57 (4): 387-407.

Brightman, Marc, Carlos Fausto, and Vanessa Grotti. 2016. Introduction. In Ownership and Nurture. Studies in Native Amazonian Property Relations, ed. Marc Brightman, Carlos Fausto, and Vanessa Grotti. New York: Berghahn Books.

Bury, Jeffery. 2005. Mining Mountains: Neoliberalism, Land Tenure, Livelihoods, and the New Peruvian Mining Industry in Cajamarca. Environment and Planning A: Economy and Space 37: 221-239.

Candea, Matei. 2014. The Ontology of the Political Turn. Cultural Anthropology. https://culanth.org/fieldsights/469-the-ontology-of-the-political-turn. Accessed 18 Jan 2018.

Candente Copper Corp. 2011. Cañariaco Norte Copper Project Pre-feasibility Study Progress Report. http://www.candentecopper.com/i/pdf/CanariacoPFS.pdf. Accessed 19 Mar 2016.

Canessa, Andrew. 2017. Bearing Witness. Testimonies, Translations, and Ontologies in the Andes. HAU: Journal of Anthropological Theory 7 (1): $545-551$.

Carrasco, Alfredo. 2014. Inkawasi, la singularidad de sus expresiones culturales. Ferreñafe: CIDEC.

- 2018. Instrumentos musicales y danzas en Incahuasi. In Cañaris. Etnografías y documentos de la sierra de Lambayeque (Perú), ed. Juan Javier Rivera Andía. Buenos Aires: Colección Ethnographica, Rumbo Sur.

Carrasco, Alfredo, Julio Fernández, and Karina Villarroel. 2016. Iglisya qatay. El fervor popular en incahuasi. Chiclayo: Ministerio de Cultura.

Carrasco, Alfredo. 2018. Instrumentos musicales y danzas en Incahuasi. In Cañaris. Etnografías y documentos de la sierra de Lambayeque (Perú), ed. Juan Javier Rivera Andía. Buenos Aires: Colección Ethnographica, Rumbo Sur.

Cepek, Michael. 2016. There Might Be Blood: Oil, Humility, and the Cosmopolitics of a Cofán Petro-Being. American Ethnologist 43 (4): 623-635.

Cesarino, Pedro de Niemeyer. 2016. Doubles and Owners: Relations of Knowledge, Property and Authorship Among the Marubo. In Ownership and Nurture. Studies in Native Amazonian Property Relations, ed. M. Brightman, C. Fausto, and V. Grotti. New York: Berghahn Books.

Coelho de Souza, Marcela. 2016. The Forgotten Pattern and the Stolen Design: Contract, Exchange and Creativity Among the Kisêdjê. In Ownership and Nurture. Studies in Native Amazonian Property Relations, ed. M. Brightman, C. Fausto, and V. Grotti. New York: Berghahn Books. 
Connell, John, and Richard Howitt, eds. 1991. Mining and Indigenous Peoples in Australasia. Sydney: Sydney University Press.

De Echave, José. 2011. La minería peruana y los escenarios de transición. In Transiciones Postextractivismo y alternativas al extractivismo en el Perú, ed. Alejandra Alayza and Eduardo Gudynas. Lima: CEPES, RedGE.

De Echave, José, Alejandro Diez Hurtado, Ludwig Huber, Bruno Revesz, Xavier Ricard Lanata, and Martín Tanaka. 2009. Minería y conflicto social. Lima: IEP, CIPCA, CBC.

de la Cadena, Marisol. 2014. The Politics of Modern Politics Meets Ethnographies of Excess Through Ontological Openings. Theorizing the Contemporary. http://www.culanth.org/fieldsights /471-the-politics-of-modern-politicsmeets-ethnographies-of-excess-through-ontological-openings. Accessed 19 Mar 2016.

- 2015. Earth Beings. Ecologies of Practice Across Andean Worlds. Durham: Duke University Press.

Descola, Philippe. 2006 (2005). Beyond Nature and Culture, Radcliffe-Brown Lecture in Social Anthropology, 2005. Proceedings of the British Academy 139: $137-155$.

- 2014a. La composition des mondes. Entretiens avec pierre charbonnier. Paris: Flammarion.

- 2014b. The Difficult Art of Composing Worlds (and of Replying to Objections). Journal of Ethnographic Theory 4 (3): 431-443.

Descola, Philippe, and Tim Ingold. 2014. Etre au monde. Quelle expérience commune? Lyon: Presses Universitaires De Lyon.

Diez, Alejandro. 2012. Tensiones y transformaciones en comunidades campesinas. Lima: CISEPA, PUCP.

Di Giminiani, Piergiorgio. 2015. The Becoming of Ancestral Land: Place and Property in Mapuche Land Claims. American Ethnologist 42 (3): 490-503.

Escobar, Arturo. 2016. Sentipensar con la Tierra: Las Luchas Territoriales y la Dimensión Ontológica de las Epistemologías del Sur. AIBR, Revista de Antropología Iberoamericana 11 (01): 11-32.

Erikson, P. 2009. Obdient Things: Reflections on the Matis Theory of Materiality. In The Occult Life of Things: Native Amazonian Theories of Materiality and Personhood, ed. F. Santos-Granero, 173-190. Tucson: University of Arizona Press.

Eversole, R., John Mcneish, and A.Y. Cimadamore, eds. 2005. Indigenous Peoples and Poverty. An International Perspective. London/New York: Crop.

Fausto, Carlos. 2012 [2001]. Warfare and Shamanism in Amazonia. Cambridge: Cambridge University Press.

Fonseca Martel, César, and Enrique Mayer. 1988. Comunidad y producción en la agricultura andina. Lima: Fomciencias.

Gan, Elaine, Anne Tsing, Heather Swason, and Nils Bubandt. 2017. Introduction. Haunted Landscapes of the Anthropocene. In Arts of Living on a Damaged 
Planet, ed. A. Tsing, H. Swanson, E. Gan, and N. Bubandt. Minneapolis/ London: University of Minnesota Press.

Geertz, Clifford. 1973. Notes on the Balinese Cockfight. In The Interpretation of Cultures, ed. C. Geertz. New York: Basic Books.

Golte, Jürgen. 1987 [1980]. La racionalidad de la organización andina. Lima: IEP.

González, Eduardo. 2012. Sus muertos y los nuestros. https://latorredemarfil. lamula.pe/2012/05/30/sus-muertos-y-los-nuestros/eduardogonzalez/. Accessed 15 Feb 2018.

Gose, Peter. 1991. House Rethatching in an Andean Annual Cycle: Practice, Meaning and Contradiction. American Ethnologist 18 (1): 39-66.

Gow, Rosalind, and Bernabe Condori. 1976. Kay Pacha. Cuzco: Centro de Estudios Rurales Andinos.

Gudynas, Eduardo. 2011. Debates sobre el desarrollo y sus alternativas en América Latina: una breve guía heterodoxa. In Más allá del dessarollo. Quito: Abya Yala y Fundación Rosa Luxemburg.

- 2018. Extractivismos y corrupción en América del Sur. Estructuras, dinámicas y tendencias en una íntima relación. Revista de Ciencias Sociales y Humanas 10 (10): 73-87.

Hallam, Elizabeth, and Tim Ingold, eds. 2014. Making and Growing. Anthropological Studies of Organisms and Artefacts. Farnham: Ashgate.

Hallazi Méndez, Luis. 2013. Perú: el caso de la comunidad de cañaris y el derecho a la consulta previa. http://servindi.org/actualidad/81367. Accessed 13 Dec 2013.

Handelsman, Simon D. 2002. Human Rights in the Minerals Industry. MMSD Work. Paper No. 9. http://pubs.iied.org/pdfs/G00531.pdf. Accessed 26 Feb 2018.

High, Casey. 2015. Victims and Warriors. Violence, History and Memory in Amazonia. Champaign: University of Illinois Press.

Holbraad, Martin. 2009. Ontology, Ethnography, Archaeology: An Afterword on the Ontography of Thing. Cambridge Archaeological Journal 19 (3): 431-441. 2014. Tres Provocaciones Ontológicas. Ankulegi 18: 127-139.

. 2017. The Contingency of Concepts: Transcendental Deduction and Ethnographic Expression in Anthropological Thinking. In Comparative Metaphysics. Ontology After Anthropology, ed. P. Charbonnier, G. Salmon, and P. Skafish. London/New York: Rowman and Littlefield.

Holbraad, Martin, and Morten Axel Pedersen. 2017. The Ontological Turn. An Anthropological Exposition. Cambridge: Cambridge University Press.

Howe, Cymene. 2015. Latin America in the Anthropocene: Energy Transitions and Climate Change Mitigations. The Journal of Latin American and Caribbean Anthropology 20 (2): 231-241.

Huamaní, Giselle, and Sandro Macassi. 2011. Gestión de conflictos socio ambientales. Lima: Consorcio de Investigación Económica y Social. 
Huamaní, Giselle, Sandro Macassi, Julio Alegría, and Telmo Rojas. 2012. Hacia una major gestión de los conflictos socio ambientales en el Perú. Lima: Consorcio de Investigación Económica y Social.

Huertas, Lorenzo. 1996. Patrones de asentamiento poblacional en piura (1532-1850). Bulletin de l'Institut Français d'Etudes Andines 25 (1): 91-124.

Ingold, Tim. 2013. Making: Anthropology, Archaeology, Art and Architecture. London: Routledge.

Jorgensen, Dan. 2010. Who and What Is a Landowner? Mythology and Marking the Ground in a Papua New Guinea Mining Project. Anthropological Forum 7 (4): 599-627.

La República. 2013. Enfrentamiento por proyecto Cañariaco dejó dos heridos graves. http://larepublica.pe/politica/688546-enfrentamiento-por-proyectocanariaco-dejo-dos-heridos-graves. Accessed 26 Jan 2013.

Lanegra, Iván. 2008. El (ausente) estado ambiental. Razones para la reforma de las instituciones y las organizaciones públicas ambientales en el Perú. Lima: Realidades.

Larco, Laura. 2008. Más allá de los encantos: Documentos históricos y etnografía contemporánea sobre extirpación de idolatrías en Trujillo (siglos XVIII-XX). Lima: l'Institut Français d'Etudes Andines.

Latour, Bruno. 2009. Perspectivism: 'Type' or 'Bomb'? Anthropology Today 25 (2): $1-2$.

. 2014a. Agency at the Time of the Anthropocene. New Literary History 45: $1-18$.

- 2014b. Another Way to Compose the Common World. HAU: Journal of Ethnographic Theory 4 (1): 301-307.

- 2015. Los Modernos, Según la Antropología, N. Revista de Cultura (Clarín). http://www.revistaenie.clarin.com/ideas/Bruno-Latour-modernosantropologia_0_1295270475.html. Accessed 19 Mar 2016.

Law, John, and Marianne E. Lien. 2012. Denaturalising Nature. Public Inaugural Sawyer Seminar Talk at University of California, Davis. https://www.sv.uio. no/sai/english/research/projects/newcomers/publications/working-papersweb/denanturalisingnaturetalk2.pdf. Accessed 19 Jan 2018.

Malpica, Carlos. 1984. Los dueños del Perú. Lima: Peisa.

Martínez, Luz. 2017. Música y cantos de Incahuasi. Lima: Ministerio de Cultura.

Meléndez, Carlos. 2004. Hipótesis sobre los conflictos en el Perú actual. Secuelas y lecciones de los años de violencia política. Lima: Asociación Civil Transparencia.

Merino, Roger. 2012. Perú: en defensa de lo comunal: cinco errores en el análisis de los conflictos socio-ambientales. http://servindi.org/actualidad/65708. Accessed 13 Dec 2013.

- 2015. The Politics of Extractive Governance: Indigenous Peoples and Socio-Environmental Conflicts. The Extractive Industries and Society 2: 85-92.

Mol, Annemarie. 1999. Ontological Politics. A Word and Some Questions. The Sociological Review 47 (S1): 74-89. 
Murra, John V. 2002. El mundo andino: población, medio ambiente y economía. Lima: Pontificia Universidad Católica del Perú e Instituto de Estudios Peruanos. Nixon, Rob. 2013. Slow Violence and the Environmentalism of the Poor. Cambridge, MA: Harvard University Press.

Ombudsman's Office. 2014. Reporte de Conflictos Sociales. Lima: Defensoría del Pueblo.

Ortiz Rescaniere, Alejandro. 1999. El Individuo Andino, Autóctono y Cosmopolita. In Cultura y globalización, ed. Carlos Iván Degregori and Gonzalo Portocarrero. Lima: PUCP, Universidad del Pacífico, IEP.

Panfichi, Aldo. 2011. Contentious Representation and Its Impact in Contemporary Peru. In Fractured Politics: Peruvian Democracy Past and Present, ed. J. Crabtree. London: University of London Press.

Pérez Galán, Beatriz. 2004. 'Somos como incas'. Autoridades tradicionales en los Andes peruanos, Cuzco. Madrid: Iberoamericana.

Rajak, Dinah. 2011. Theatres of Virtue: Collaboration, Consensus and the Social Life of Corporate Social Responsibility. Focaal 60: 9-20.

Rajak, Dinah, and Emma Gilberthorpe. 2016. The Anthropology of Extraction: Critical Perspectives on the Resource Curse. Journal of Development Studies 53 (2): 186-204.

Rappaport, Roy. 1999. Ritual and Religion in the Making of Humanity. Cambridge: Cambridge University Press.

Rénique, Gerardo. 2009. Law of the Jungle in Peru: Indigenous Amazonian Uprising Against Neoliberalism. Socialism and Democracy 23 (3): 117-135.

Rivera Andía, Juan Javier. 2000. Los gentiles de Llampa. Anthropologica 18: 271-280.

-2003. La fiesta del Ganado en el Valle del Chancay. Lima: PUCP.

- 2005. Territorio e identidad en los Andes. Concepciones populares en torno a las zonas ecológicas altas en la sierra de Lima. Revista de Dialectología $y$ Tradiciones Populares 40 (2): 55-76.

-2008. Apuntes sobre la alteridad constituyente en los Andes. Ambivalencias rituales y lingüísticas sobre un espacio imaginario. Revista española de antropología americana 38 (1): 191-215.

- 2013. Un Patrimonio cultural ignorado y en riesgo en los Andes septentrionales del Perú. Apuntes etnográficos sobre dos instrumentos musicales endémicos de la sierra de Lambayeque. In Wege im Garten der Ethnologie. Zwischen dort und hier. Festschrift für Maria Susana Cipolletti (Collectanea Instituti Anthropos, 46), eds. Hanna Heinrich and Harald Grauer. Sankt Augustin: Anthropos Institut.

- 2014a. Fears and Rituals in Contemporary Peruvian Andes. In The Anthropology of Fear. Cultures Beyond Emotions, ed. A. Boscoboinik and H. Horáková. Berlin: LIT Verlag.

— 2014b. Fuentes para el estudio de una región 'invisible' de los Andes Peruanos: Contribución para una bibliografía exhaustiva sobre la sociedad y la 
naturaleza en la sierra de Lambayeque, Perú. Anuario Americanista Europeo 12: 47-77.

- 2015a. Amerindian Misfortunes: Ethnographies of South American Rituals and Cosmologies on Danger, Illness, and Evil. Indiana 32: 9-22.

- 2015b. La iglesia de incahuasi. Notas sobre antropología simétrica, arquitectura e historia en los Andes peruanos septentrionales (ferreñafe, lambayeque). Revista española de antropología americana 45 (2): 551-568.

- 2016. Nuevos estudios sobre la peculiar iglesia virreinal de Incahuasi y la historia de una región postergada de los Andes (área Cañaris, Lambayeque, Perú). Indiana 33 (2): 145-160.

Rivera Andía, Juan Javier, and Peter Snowdon. 2013. The Owners of the Land. Culture and the Spectre of Mining in the Andes. Genk: Het Vervolg.

Rivera Andía, Juan Javier, José Cajo, Cristóbal Barrios, and José Gaspar. 2017. ¿Quiénes son los cañaris del perú? Aspectos históricos y etnológicos de la relación con la tierra y el medioambiente de un pueblo ignorado y amenazado en la sierra de lambayeque. In El concepto de lo sagrado en el mundo andino antiguo: espacios y elementos pan-regionales, ed. A. Yépez, V. Moscovich, and C. Astuhuamán. Quito: PUCE.

Robin, Valerie. 2010. La petrificación de los antiguos en Chumbivilcas (Cuzco, Perú). De la wanka prehispánica al actual ramadero. Revista Española de Antropología Americana 40 (1): 219-238.

Salas Carreño, Guillermo. 2008. Dinámica social y minería. Familias pastoras de puna y la presencia del proyecto Antamina (1997-2002). Lima: IEP.

- 2016. Places are Kin: Food, Cohabitation, and Sociality in the Southern Peruvian Andes. Anthropological Quarterly 89 (3): 813-840.

Salvia, Daniela Di. 2014. La religión de la tierra en los Andes centrales: Imágenes simbólicas y trasnfondos ecológicos. Salamanca: Vitor.

Schavelzon, Salvador. 2016. La política indígena y la investigación en Bolivia. Revista de Antropologia 59 (3): 115-149.

Shaver, D. 1992. Organización socio-política de las comunidades campesinas: el caso de Inkawasi. In Estudios Etno-Lingüísticos II, ed. S. Parker. Lima: Ministerio de Educación-Instituto Lingüístico de Verano.

Silva Santisteban, Rocío. 2013. 96\% del distrito de Cañaris está concesionado. En: La República (01.05.2013). http://larepublica.pe/politica/708069-96-deldistrito-de-canaris-esta-concesionado. Accessed 26 Feb 2018.

Sotelo, Vicente, and Pedro Francke. 2011. ¿Es económicamente viable una economía postextractivista en el Perú? In Transiciones Postextractivismo y alternativas al extractivismo en el Perú, ed. Alejandra Alayza and Eduardo Gudynas. Lima: CEPES, RedGE.

Stengers, Isabelle. 1996. Cosmopolitiques. T1. La guerre des sciences. Paris: La Découverte.

Tanaka, Martín. 2012. ¿Por qué el Estado no responde adecuadamente a los conflictossociales? ¿Qué hacer al respecto? Economía y Sociedad 79: 36-43. 
Tomasi, Jorge. 2015. The House as a Moving Story: An Ethnography of Andean Domestic Architecture. In Vernacular Architecture: Towards a Sustainable Future, ed. C. Mileto, F. Vegas, L. García Soriano, and V. Cristini, 701-706. London: CRC Press.

Urrutia, Jaime. 1992. Comunidades campesinas y antropología: historia de un amor (casi) eterno. Debate Agrario 14: 1-16.

Viegas, Susana de Matos. 2016. Temporalities of Ownership: Land Possession and Its Transformations Among the Tupinambá (Bahia, Brazil). In Ownership and Nurture. Studies in Native Amazonian Property Relations, ed. Marc Brightman, Carlos Fausto, and Vanessa Grotti. New York: Berghahn Books.

Viveiros de Castro, Eduardo. 1999. Comments to 'Animism Revisited: Personhood, Environment, and Relational Epistemology'. Current Anthropology 40: 79-80.

- 2015a. The Relative Native. Essays on Indigenous Conceptual Worlds. Chicago: Hau Books.

- 2015b. Who Is Afraid of the Ontological Wolf? Some Comments on an Ongoing Anthropological Debate. The Cambridge Journal of Anthropology 33 (1): 2-17.

Vreeland, James. 1993. Danzas tradicionales de la sierra de lambayeque. In Música, danzas y máscaras en los Andes, ed. R. Romero. Lima: Pontificia Universidad Católica del Perú.

Weszkalnys, Gisa. 2016. A Doubtful Hope: Resource Affect in a Future Oil Economy. Journal of the Royal Anthropological Institute 22 (S1): 127-146.

Open Access This chapter is licensed under the terms of the Creative Commons Attribution 4.0 International License (http://creativecommons.org/licenses/ by $/ 4.0 /)$, which permits use, sharing, adaptation, distribution and reproduction in any medium or format, as long as you give appropriate credit to the original author(s) and the source, provide a link to the Creative Commons license and indicate if changes were made.

The images or other third party material in this chapter are included in the chapter's Creative Commons license, unless indicated otherwise in a credit line to the material. If material is not included in the chapter's Creative Commons license and your intended use is not permitted by statutory regulation or exceeds the permitted use, you will need to obtain permission directly from the copyright holder.

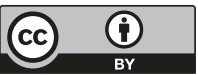

